Int. J. Electrochem. Sci., 15 (2020) 3517 - 3533

\title{
Development and Validation of Electrochemical Method for Quantification of Palbociclib (Anticancer Agent) in Biological Matrices Using Square Wave- Adsorptive Stripping Voltammetry
}

\author{
Ali F. Alghamdi ${ }^{1, *}$, Mohamed Hefnawy ${ }^{2}$,Sara Al-Rashood ${ }^{2}$ \\ ${ }^{1}$ Department of Chemistry, College of Science, Taibah University, P. O. Box 30002, Medina, Saudi \\ Arabia \\ ${ }^{2}$ Department of Pharmaceutical Chemistry, College of Pharmacy, King Saud University, P. O. Box \\ 2457, Riyadh 11451, Saudi Arabia \\ *E-mail: alifh2006@ hotmail.com
}

doi: $10.20964 / 2020.04 .31$

Received: 28 September 2019 / Accepted: 23 January 2020 / Published: 10 March 2020

The electrochemical reduction behavior of palbociclib (PLB) was studied using square wave voltammetry, differential pulse polarography and cyclic voltammetry in Britton-Robinson (B-R) buffer of $\mathrm{pH}$ 7.0. The mercury electrode was used to accumulate PLB into its surface to give a well-defined reduction wave at $-1.05 \mathrm{~V}$ potential in the presence of $\mathrm{Ag} / \mathrm{AgCl}$ reference electrode and $\mathrm{Pt}$ auxiliary electrode. There were some analytical parameters which studied to obtain the best reduction signal, such as buffer solutions (types and strength), $\mathrm{pH}$ values, scans and stirring rates. Britton-Robinson buffer of $\mathrm{pH} 7.0,50 \mathrm{~s}$ accumulation time, $0.0 \mathrm{~V}$ accumulation potential, $30 \mathrm{~Hz}$ frequency, $300 \mathrm{mV} \mathrm{s}^{-1}$ scan rate, $50 \mathrm{mV}$ amplitude, $0.6 \mathrm{~mm}^{2}$ drop area, and $3000 \mathrm{rpm}$ were recorded high sensitivity for the PLB determination, so they were chosen as optimum parameters for the next work. The repeatability, stability, recovery, calibration curve and detection limit were validated to evaluate the analytical performance of the developed method. Repeatability and stability of $5 \times 10^{-7} \mathrm{~mol} \mathrm{~L}^{-1}$ of PLB were reported $0.0282 \%$ relative standard deviation (RSD\%) for ten cathodic measurements, and a good stability for $120 \mathrm{~min}$, respectively. Calibration curve was studied over the range $1 \times 10^{-7}-1 \times 10^{-6} \mathrm{~mol}$ $\mathrm{L}^{-1}$ for PLB to be obtained a linear relationship with a 0.992 correlation coefficient $\left(\mathrm{r}^{2}\right)$ for sex measurements $(\mathrm{n}=6)$. Lower detection limit (LOD) was calculated to be $8.8 \times 10^{-11} \mathrm{~mol} \mathrm{~L}^{-1}(0.039$ $\mathrm{ppb}$ ), while lower quantification limit (LOQ) was become $2.9 \times 10^{-10} \mathrm{~mol} \mathrm{~L}^{-1}(0.131 \mathrm{ppb})$. The square wave voltammetry method was applied for qantification of PLB at the human plasma and urine samples.

Keywords. Voltammetry, reduction behavior, palbociclib, human plasma, mercury electrode, buffer solution. 


\section{FULL TEXT}

(C) 2020 The Authors. Published by ESG (www.electrochemsci.org). This article is an open access article distributed under the terms and conditions of the Creative Commons Attribution license (http://creativecommons.org/licenses/by/4.0/). 